\title{
Ontological Base Information System in Higher Education
}

\author{
Bagus Mulyawan, Meyliana, Achmad Nizar Hidayanto, Harjanto Prabowo
}

\begin{abstract}
Higher education institutions that produce various documents of scientific information on learning outcomes need tools that can accommodate stakeholders in utilizing various data that has been generated. The application of ontology-based systems can be very helpful in managing knowledge data based on keywords that are difficult to do with traditional methods. In this study aims to find out various studies that have been carried out about ontology base application of information systems in higher education institutions. The steps include the study of literature sourced from major databases such as Science Direct, IEEE Explore Digital Lirary, ACM Digital Library and others credible sources. Set through the selection criteria and data extraction this study from 195 papers, 21 papers were analyzed. The results of the analysis of this paper conclude that the information system that has been developed in Higher Education is an ontology application that is used to carry out various evaluation processes in education, e-learning, academic recommendations, information search, higher education companies, content analysis, knowledge management, documentation, education company, syllabus, knowledge management, and others. From this research it appears that various ontology-based applications have been developed for various information system needs in higher education, where the aim is to facilitate the search for various types of scientific documents and supporting documents precisely and quickly. For application development, the OWL language is the most widely used choice and the protege as a development tool is the main choice of researchers.
\end{abstract}

Keywords: Ontology; university; application; information system; higher education

\section{INTRODUCTION}

Every day various documents and data are produced by universities. A search for a type of document performed by humans can lot of information found, but it is difficult to do with computer technology, by using the ontology model it

Revised Manuscript Received on February 05, 2020.

* Correspondence Author

Bagus Mulyawan , BINUS Graduate Program, Doctor of Computer Science, Bina Nusantara University, Jakarta \& Faculty of Information Technology, Universitas Tarumanagara, Jakarta Indonesia 11440.

Email: bagus.mulyawan@hotmail.com.

Meyliana*, Information System Department, School of Information Systems, Bina Nusantara University, Jakarta 11480, Indonesia.Email: meyliana@binus.edu

Achmad Nizar Hidayanto, Faculty of Computer Science, Universitas Indonesia, Depok, 16424, Indonesia. Email: nizar@cs.ui.ac.id

Harjanto Prabowo, Management Department, BINUS Business School, Undergraduate Program, Bina Nusantara University, Jakarta 11480, Indonesia.Email:harprabowo@binus.edu

(C) The Authors. Published by Blue Eyes Intelligence Engineering and Sciences Publication (BEIESP). This is an open access article under the CC BY-NC-ND license (http://creativecommons.org/licenses/by-nc-nd/4.0/) will be more efficient and easier [1]. The important thing that becomes an issue in Higher Education is access to research and teaching activities. [2] Education is the most important factor in any society. The determinant of success in developing countries is education. [3] Higher education is an institution that continuously produces knowledge. Therefore the results of academic and administrative activities need to be saved. With the increasing variety of information available in higher education, technology is needed to represent knowledge to organize and manage it. The technology is very adequate and is widely used to represent knowledge.[1]. This study aims to determine the application of ontology-based applications in higher education in terms of the development tools used, the applications applied and the language used. The composition of this paper consists of; part 2 explains the concept of ontology, part 3 explains the method used, part 4 explains the results obtained , part 5 explains the conclusions and part 6 explain limitation.

\section{LITERATURE REVIEW}

\section{A.Ontology}

Thomas Gruber [4], in general, has explained that what is mean by ontology is "the formal and explicit specifications of a joint conceptualization". With another understanding explaining the pattern of relationships between various domains such as health, education, and knowledge management and others which are compiled explicitly mention the name of the concept and its relationship.

B. Applications

According to [2] some users of ontology in various fields including following:

- Natural language processing: is a field of linguistics and artificial intelligence related to human interaction with computers using natural language.

- Educational Ontologies: Application of the concept of ontology to support various processes in higher education.

- Tagging of Resources: This type is a classification method for finding new information automatically and thorough advantages.

According to [3] Utilization of ontology has many advantages including the following:

- $\quad$ One of the goals of ontology is to share an understanding of the structure of information between humans or software agents

- Ontology enables the reusability of domain knowledge in representing concepts and their relationships.

- Allows changing the ontology assumption easily if there is a change in the ontology domain

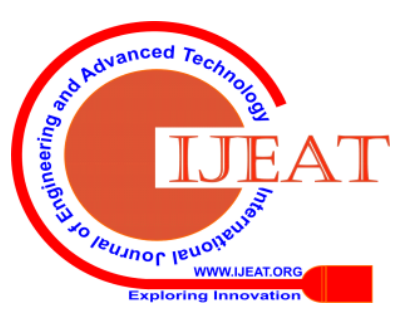




\section{Ontological Base Information System in Higher Education}

- $\quad$ Based on the provisions contained in the document, knowledge domain analysis can be done using ontology.

- Software developed based on ontology can translate data that can be understood by machines.

- It can help express the perspective of software development.

\section{C.Ontology Development Component}

\section{Ontology Language}

Following are the languages used for the development of ontology-based applications[4]:

- Extended Markup Language (XML) is Markup languages separate web appearance from web content, the main disadvantage is the lack of semantic aspects, although it is widely used as a standard for displaying web information.

- Resource Description Framework (RDF) is Consists of subjects, predicates, and objects which are also called triple, which allows the exchange of information that is understood by the machine.

- Ontology Interface Layer (OIL) was The language used to exchange frame-based ontology, logical descriptions and web-based

- DAML+OILare Is an ontology language that is a DARPA Agent Markup language combination with OIL.

- XML-based Ontology Exchange Language (XOL) is designed as a framework to exchange ontology definition.

- Simple HTML Ontology Language (SHOE) Is Is an increase in the ability of HTML pages to be machine-readable.

- Web Ontology Language (OWL) is an increase in the ability of HTML pages to be machine-readable.

\section{Ontology Development Tool}

According to [5] various ontology development tools can be seen at Tabel-I.

Table-I: Ontology Development Tools

\begin{tabular}{|c|c|c|}
\hline No. & Development Tool & Main Feature \\
\hline 1 & OilEd & Ontology editor using OIL \\
\hline 2 & OntoEdit & Ontology editor \\
\hline 3 & WebODE & $\begin{array}{l}\text { Support for } \\
\text { ontology lifecycle, } \\
\text { ontology development } \\
\text { methodologies, and } \\
\text { ontology } \\
\text { interoperability }\end{array}$ \\
\hline 4 & Protégé & $\begin{array}{l}\text { An open-source tool } \\
\text { For developers }\end{array}$ \\
\hline 5 & OntoSaurus & Ontology browser \\
\hline 6 & Ontolingua & $\begin{array}{l}\text { Provides modular ontology } \\
\text { authoring tools and library } \\
\text { facilities for reuseable } \\
\text { ontology. }\end{array}$ \\
\hline 7 & KOAN & $\begin{array}{l}\text { Provides features for } \\
\text { ontology and metadata, } \\
\text { negineering, discovery and } \\
\text { management presentations }\end{array}$ \\
\hline 8 & SymOntoX & $\begin{array}{l}\text { Ontology management } \\
\text { system } \\
\text { for developing and } \\
\text { managing several } \\
\text { ontologies }\end{array}$ \\
\hline 9 & Retrievalware 8.0 & $\begin{array}{l}\text { An enterprise search engine } \\
\text { that emphasizes } \begin{array}{r}\text { using } \\
\text { semantic and natural } \\
\text { language. }\end{array}\end{array}$ \\
\hline
\end{tabular}
applied in higher education.

\section{A.Research Question} process.

\section{B. Search Strategy} were obtained.

\section{C.Selection criteria process.} analysis process. presented at the conference.

articles 195 papers were obtained. From these papers then read the titles, abstracts, and keywords to carry out the inclusion criteria process and obtained 84 paper candidates that will be examined. Then from the extraction results and data analysis obtained 21 primary studies. The analysis was carried out based on the research questions. The results of the process can be seen in TABLE 2 . The phase literature study process illustrated in the figure. 1 which consists of three phases, (1) search paper in the database (IEEE Explore Digital Lirary , ACM Digital Lirary , ScienceDirect and Others), (2) Filter by title, abstract and keywords, (3) read full papers and (4) select primary paper. Searching for specific categories related to research in the field of ontology that is

In this study, there are 3 research questions, namely RQ1: What applications are based ontologies that applied in higher education. RQ2: What development tools used to develop applications. RQ3: What language used for the development

Scientific research is available in computer science-related repositories: ACM Library, IEEE Explore, Science Direct and Others. The keywords "Higher Education" and ontology * are used for search. From this search strategy, 195 papers

In this phase, the researcher ensures that only research related to ontology related to education will be analyzed. By doing the categorization and selection of articles the researcher can determine whether an article will be included in the next

Papers that meet the criteria to be further analyzed will be carried out. These criteria include complete papers, educational papers using ontology concepts and papers from conferences and scientific journal papers.

Papers that have at least one of the following criteria will be issued, namely, papers that discuss ontology philosophy, papers without educational context, papers written not in English, books, book chapters or reports. In this phase, the researcher determines studies related to ontology related to education by carrying out the process of inclusion and exclusion. Papers that will be further processed are papers that apply ontology to education, scientific articles or papers

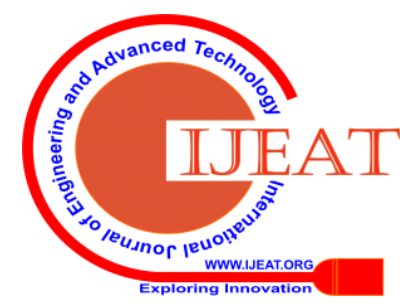




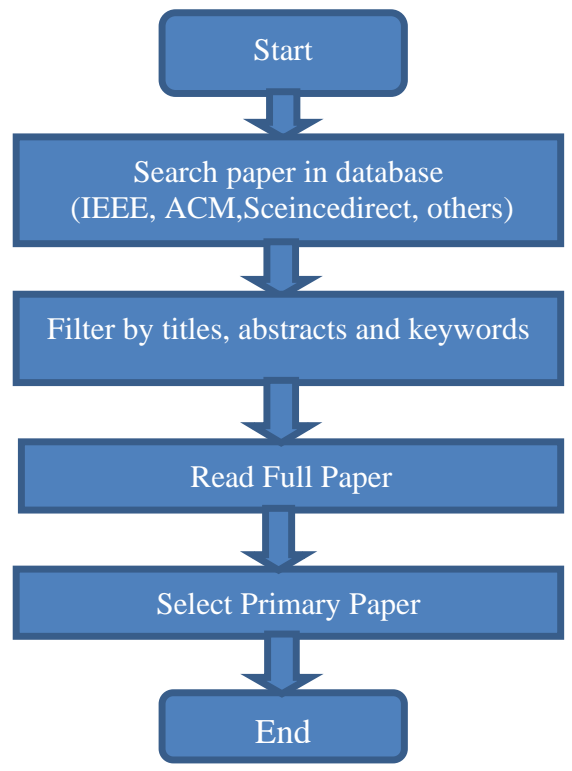

Fig. 1. Phase decision literature study

After obtaining the results of the search process and various duplicates are eliminated the selection process is done by reading the title, abstract and keywords after the analysis process of the paper are done the exclusion process.

\section{Data Extraction}

The data extraction process aims to carry out classification based on research questions, from 195 papers analyzed, there are 84 potential papers to be candidates for analysis. After the analysis process, there were only 21 papers used for this study. The result of this process is shown in Table II.

\section{Table-II: Selected Paper}

\begin{tabular}{|l|r|r|r|}
\hline Source & Found & Candidate Studies & $\begin{array}{l}\text { Selected } \\
\text { studies }\end{array}$ \\
\hline Science Direct & 74 & 28 & 8 \\
\hline ACM Digital & 53 & 14 & 1 \\
Library & & & 9 \\
\hline IEEE Explore & 45 & 32 & 3 \\
\hline Others & 23 & 10 & $\mathbf{2 1}$ \\
\hline Total & $\mathbf{1 9 5}$ & $\mathbf{8 4}$ & (95 \\
\hline
\end{tabular}

There are 7 journal articles and 18 conference proceeding article selected. The summary selected article could be seen in Table 3.

\section{TABLE-III: Source of Publications}

\begin{tabular}{|c|c|c|c|}
\hline No. & Title & Year & Type \\
\hline 1 & FML-based knowledge.... [6] & 2012 & $\mathrm{C}$ \\
\hline 2 & Towards Information ......[7] & 2015 & $\mathrm{C}$ \\
\hline 3 & Application of .......[1] & 2018 & $\mathrm{C}$ \\
\hline 4. & Ontology for Academic....[2] & 2016 & $\mathrm{~J}$ \\
\hline 5. & Ontology Development .....[3] & 2001 & $\mathrm{~J}$ \\
\hline 6. & An ontology-based...[4] & 2015 & $\mathrm{~J}$ \\
\hline 7. & Emerging of Academic...[5] & 2014 & $\mathrm{C}$ \\
\hline 8. & A novel ontology-based...[8] & 2018 & $\mathrm{C}$ \\
\hline 9. & Faculty performance ...[9] & 2014 & $\mathrm{C}$ \\
\hline 10. & Personalized feedback ...[10] & 2016 & $\mathrm{~J}$ \\
\hline 11. & CONALI Ontology...[11] & 2016 & $\mathrm{~J}$ \\
\hline 12. & Ontology-based document...[12] & 2014 & $\mathrm{C}$ \\
\hline 13. & Ontology-based e-learning...[13] & 2011 & $\mathrm{~J}$ \\
\hline 14. & Using linked data ...[14] & 2011 & $\mathrm{~J}$ \\
\hline 15 & Ontology-based ...[15] & 2018 & $\mathrm{C}$ \\
\hline 16. & Ontology-Based ...[16] & 2019 & $\mathrm{~J}$ \\
\hline 17. & An application of ...[17] & 2017 & $\mathrm{~J}$ \\
\hline 18. & Modeling instructional...[18] & 2011 & $\mathrm{~J}$ \\
\hline 19. & An approach ...[19] & 2012 & $\mathrm{C}$ \\
\hline 20. & Developing Ontology ...[20] & 2014 & $\mathrm{C}$ \\
\hline 21. & Self-study support ...[21] & 2012 & $\mathrm{C}$ \\
\hline 22. & The Design of Quality ...[22] & 2013 & $\mathrm{C}$ \\
\hline 23. & Ontologies in ...[23] & 2015 & $\mathrm{C}$ \\
\hline
\end{tabular}

\begin{tabular}{|l|l|l|l|}
\hline 24. & Semantic-based ...[24] & 2011 & C \\
\hline 25. & Personalized learning ...[25] & 2015 & C \\
\hline
\end{tabular}

\section{RESULT}

In the search process, the researchers obtained 194 papers from a repository of reputable scientific articles. The next step is to read keywords, abstracts, and titles. Then the inclusion criteria process was carried out, in which 84 papers were obtained from the process. The next step is to carry out the data extraction and analysis process. 21 papers were obtained from this process. The paper is then analyzed based on research questions. The results can be seen in TABLE IV.

Table-IV: Result Study Literature

\begin{tabular}{|c|c|c|c|}
\hline RQ & Options & $\begin{array}{l}\text { Numbers of } \\
\text { Studies }\end{array}$ & Percentage (\%) \\
\hline \multirow[t]{12}{*}{ RQ1 } & Application & & \\
\hline & Academic evaluation & 5 & $24 \%$ \\
\hline & $\begin{array}{l}\text { Academic } \\
\text { recommendation }\end{array}$ & 2 & $10 \%$ \\
\hline & E-learning & 4 & $19 \%$ \\
\hline & $\begin{array}{ll}\text { Higher } & \text { education } \\
\text { enterprise } & \\
\end{array}$ & 1 & $5 \%$ \\
\hline & Sylabus & 1 & $5 \%$ \\
\hline & Information retrieval & 2 & $10 \%$ \\
\hline & Documentation & 1 & $5 \%$ \\
\hline & Knowledge Management & 1 & $5 \%$ \\
\hline & Content analysis & 1 & $5 \%$ \\
\hline & Others purposes & 3 & $14 \%$ \\
\hline & Total & 21 & $100 \%$ \\
\hline \multirow[t]{5}{*}{ RQ2 } & Development Tools & & \\
\hline & Protégé & 12 & $57 \%$ \\
\hline & $\mathrm{HO}-\mathrm{ZO}$ & 1 & $5 \%$ \\
\hline & Other & 8 & $38 \%$ \\
\hline & Total & 21 & $100 \%$ \\
\hline \multirow[t]{6}{*}{ RQ3 } & Language & & \\
\hline & XML & 1 & $5 \%$ \\
\hline & SWRL & 2 & $10 \%$ \\
\hline & OWL & 13 & $61 \%$ \\
\hline & Other & 5 & $24 \%$ \\
\hline & Total & 21 & $100 \%$ \\
\hline
\end{tabular}

\section{A. RQ1. Application in Higher Education}

Based on the results of a study of 21 papers aspects developed regarding the use of the ontology model for evaluating activities in Higher Education are as follows:

\section{Academic evaluation}

- It is a solution to visually discover learning outcomes to map student results and help school committees or curricula avoid over mapping or under mapping[2]

- Development of ontology-based methods to assess requirements and provide information to predict learning styles [8].

- Development of models for automatically evaluating faculty members in tertiary institutions. The evaluation system is designed using Protégé ontology editor, Web Rule Language (SWRL) and Jena ontology API.[9]

- Development of a framework based on web technology for self-assessment feedback that is suitable for a lifetime learning environment.[10]

- This paper study about Ontology-based tool used for engineering programs and evaluating activities that are aligned.[11]

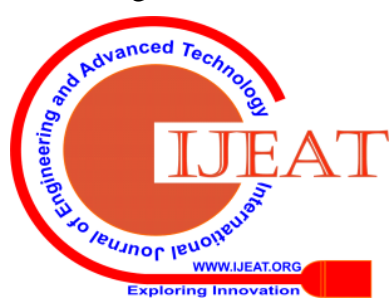




\section{Ontological Base Information System in Higher Education}

\section{E-learning}

In addition to the evaluation process, various studies based on ontology are electronic learning. There are 4 papers that study the development of ontology-based applications to improve electronic learning, the aspects of concern are as follows:

- Monitor student behavior to explore the propose e-learning system.[4]

- Make a model to determine the unambiguous learning process and partial implementation of the learning process[12]

- The study of the development of e-learning systems that can meet the needs of students with special need based ontology[13]

- Allows users to browse educational video sources that are linked semantically with enhanced web information from various online sources. [14].

\section{Recommendation}

- Provides recommended department and university features that are appropriate for students based on their interests, preference, and capabilities. [15]

- The paper that applies ontology that aims to provide integrated information as an ontology-based source for efficiency and user satisfaction and to give students appropriate recommendations.[16].

\section{Higher Education Enterprise}

- Investigate and develop a methodology to analyze organizational data in order to evaluate the level of the achievement of the organizational goals [17],

\section{Information retrieval}

- Development of an academic information system to help students who do not have research experience to obtain the resources needed in the context of using local languages (Malaysia). It was developed by comparing the various development tools used. [5]

- The purpose of this paper is to highlight the main elements of the learning model.[18]

\section{Knowledge Management}

- This paper describes the application for university governance using fuzzy ontology and fuzzy markup language to extract knowledge.[6]

\section{Content analysis}

- This paper describes the development of ontology-based applications for corporate social responsibility with a content analysis approach.[19]

8. Syllabus

- This paper describes the use of an ontology to define the order and rules of study for self-study using lecture content.[21]

\section{Documentation}

This paper explains the development of a repository for institutions to accommodate research and teaching results including research papers, patents, theses, teaching materials and etc.[20]

\section{Others}

Differences in ontology extending to a concrete example (application ontology) on the one and a wider domain area (occupational).[23].

- An Online Outcome-Based Education (OBE) measurement system, which promotes In this paper describes a centralized repository-based ontology system that can be accessed by multi-users online [24].

- An ontology that will facilitate the development of learning models and methods that are appropriate with dyslexia types and symptoms.[25]

\section{RQ2: Tool development}

To develop ontology-based systems, many choices of development tools can be used. Some of them are protege, Ho-Zo, OntoEdit, OntoSaurus, Ontolingua and many more. Based on the study results that most papers (57\%) use Protege, a minor percentage (5\%) using $\mathrm{HO}-\mathrm{ZO}$ and (38\%) the author does not provide a description of the tool used. study result illustrated in the show at Tabel-5.

\section{Tabel - V: Tool Development}

\begin{tabular}{|l|l|c|c|}
\hline $\begin{array}{c}\text { Development } \\
\text { Tool }\end{array}$ & \multicolumn{1}{|c|}{ Article } & $\begin{array}{c}\text { Number } \\
\text { of study }\end{array}$ & $\begin{array}{c}\text { Perc } \\
\text { enta } \\
\text { ge }\end{array}$ \\
\hline Protege & $\begin{array}{l}{[2],[4],[5],[8],[9],[10][11],[13],} \\
{[14],[17],[20],[23]}\end{array}$ & 12 & $57 \%$ \\
\hline HO-ZO & {$[21]$} & 1 & $5 \%$ \\
\hline Others & {$[6],[12],[15][16][18][19],[21],[24]$} & 8 & $38 \%$ \\
\hline & Total & 21 & $\begin{array}{c}100 \\
\%\end{array}$ \\
\hline
\end{tabular}

\section{RQ3: Language}

Based on the results of studies on the language used for ontology-based application development most use OWL (57\%), while around (10\%) use SWRL, at least (10\%) use XML while around (5\%) the author does not explain the language used. Tabel VI shows some language used to ontology application development

Table-VI: Ontology Language

\begin{tabular}{|l|l|r|r|}
\hline $\begin{array}{c}\text { Langua } \\
\text { ge }\end{array}$ & \multicolumn{1}{|c|}{ Article } & $\begin{array}{c}\text { Number of } \\
\text { study }\end{array}$ & Percentage \\
\hline OWL & $\begin{array}{l}{[2],[14],[4],[8],[6} \\
],[10],[11],[13],[ \\
18], \\
{[20],[23],[24]}\end{array}$ & 12 & $57.14 \%$ \\
\hline XML & {$[6]$} & 1 & \\
\hline SWRL & {$[9],[18]$} & 2 & $4.76 \%$ \\
\hline Others & $\begin{array}{l}{[1],[12],[15],[16]} \\
,[19],[21]\end{array}$ & 6 & $28.57 \%$ \\
& & & \\
\hline & Total & & \\
\hline
\end{tabular}




\section{CONCLUSION}

The utilization of ontology for application development has advantages and benefits for organizations in general and universities, in particular, to find information in accordance with the wishes of users through natural language understood by computer machines.

Higher education institutions that produce various documents of scientific information on learning outcomes need tools that can accommodate stakeholders in utilizing various data that has been generated. The application of ontology-based systems can be very helpful in managing knowledge data based on keywords that are difficult to do with traditional methods.

From the results of this study related to information systems in higher education that have been developed based on ontology from 21 selected papers and analysis of the utilization of information systems in tertiary-based higher education based on the highest number is for the college evaluation process, this can be understood because in the evaluation process may require supporting documents that require ease of availability and search. Other applications that are widely used are systems for electronic learning, syllabus preparation, recommendation systems, knowledge management, information retrieval, documentation, and others. For application development, the OWL language is the most widely used choice and protege as a development tool is the main choice of researchers.

\section{LIMITATION}

The limited number of papers used as study material causes the results obtained and does not yet cover the various types of information systems implemented in higher education.

\section{REFERENCES}

1. M. Tapia-Leon, A. C. Rivera, J. Chicaiza, and S. Lujan-Mora, "Application of ontologies in higher education: A systematic mapping study," IEEE Glob. Eng. Educ. Conf. EDUCON, vol. 2018-April, pp. 1344-1353, 2018.

2. J. Alomari, "Ontology for Academic Program Accreditation Ontology of Accreditation Board of Engineering and Technology(ABET) Process," Int. J. Adv. Comput. Sci. Appl., vol. 7, no. 7, pp. 123-127, 2016.

3. N. F. Noy and D. L. McGuinness, "Ontology Development 101: A Guide to Creating Your First Ontology," Stanford Knowl. Syst. Lab., p. 25, 2001.

4. M. Rani, R. Nayak, and O. P. Vyas, "An ontology-based adaptive personalized e-learning system, assisted by software agents on cloud storage," Knowledge-Based Syst., vol. 90, pp. 33-48, 2015.

5. N. M. Zaid and S. K. Lau, "Emerging of Academic Information Search System with Ontology-based Approach," Procedia - Soc. Behav. Sci., vol. 116, pp. 132-138, 2014.

6. C. H. Liu, C. S. Lee, M. H. Wang, Y. Y. Tseng, and Y. L. Kuo, "FML-based knowledge management system for university governance and management assessment," IEEE Int. Conf. Fuzzy Syst., no. 4, pp. 10-15, 2012.

7. A. O. Approach, "Towards Information Management System for Licensing in Higher Education: Towards Information Management System for Licensing in Higher Education: An Ontology-Based Approach," no. June, 2015.

8. S. Rami, S. Bennani, and M. K. Idrissi, "A novel ontology-based automatic method to predict learning style using felder-silverman model,” 2018 17th Int. Conf. Inf. Technol. Based High. Educ. Training, ITHET 2018, pp. 1-5, 2018.

9. S. Bai, Q. Rajput, S. Hussain, and S. A. Khoja, "Faculty performance evaluation system: An ontological approach," Proc. IEEE/ACS Int. Conf. Comput. Syst. Appl. AICCSA, vol. 2014, pp. 117-124, 2014.

10.L. Cheniti Belcadhi, "Personalized feedback for self assessment in lifelong learning environments based on semantic web," Comput. Human Behav., vol. 55, pp. 562-570, 2016.

11.A. Maffei, L. Daghini, A. Archenti, and N. Lohse, "CONALI Ontology A Framework for Design and Evaluation of Constructively Aligned Courses in Higher Education: Putting in Focus the Educational Goal Verbs," Procedia CIRP, vol. 50, pp. 765-772, 2016.

12.E. M. Popa, D. Hunyadi, and I. Pah, "Ontology-based document-driven memory for e-Learning," no. May, 2014.

13.J. T. Nganji, M. Brayshaw, and B. Tompsett, "Ontology-based e-learning personalisation for disabled students in higher education," Ital. Innov. Teach. Learn. Inf. Comput. Sci., vol. 10, no. 1, pp. 1-11, 2011.

14.H. Q. Yu, C. Pedrinaci, S. Dietze, and J. Domingue, "Using linked data to annotate and search educational video resources for supporting distance learning,” IEEE Trans. Learn. Technol., vol. 5, no. 2, pp. 130-142, 2012.

15.C. Obeid, I. Lahoud, H. El Khoury, and P.-A. Champin, "Ontology-based Recommender System in Higher Education,” vol. 2, pp. 1031-1034, 2018.

16.M. E. Ibrahim, Y. Yang, D. L. Ndzi, G. Yang, and M. Al-Maliki, "Ontology-Based Personalized Course Recommendation Framework," IEEE Access, vol. 7, no. c, pp. 5180-5199, 2019.

17.T. A. T. Izhar, T. Torabi, and M. Ishaq Bhatti, "An application of the ontology based goal-framework in a higher education institution in australia: A case study,” Int. J. Comput. Inf. Syst. Ind. Manag. Appl., vol. 9, no. 2017, pp. 43-59, 2017.

18.M. Á. Sicilia, M. D. Lytras, S. Sánchez-Alonso, E. García-Barriocanal, and M. Zapata-Ros, "Modeling instructional-design theories with ontologies: Using methods to check, generate and search learning designs," Comput. Human Behav., vol. 27, no. 4, pp. 1389-1398, 2011.

19.A. Esfijani, F. K. Hussain, and E. Chang, "An approach to university social responsibility ontology development through text analyses," Int. Conf. Hum. Syst. Interact. HSI, pp. 1-7, 2012.

20.D. Kyriaki-Manessi and M. Dendrinos, "Developing Ontology for the University Archives: The Domain of Technological Education," Procedia - Soc. Behav. Sci., vol. 147, pp. 349-359, 2014.

21.T. Saitoh, R. Yaegashi, and T. Hayashi, "Self-study support system using the lecture contents: Creation of study ontology from syllabuses," 2012 Int. Conf. Inf. Technol. Based High. Educ. Training, ITHET 2012, 2012.

22.I. Sartika, "The Design of Quality Documentation System at Higher Education Using ISO 9000 Model," Procedia - Soc. Behav. Sci., vol. 103, pp. 982-990, 2013.

23.S. Lovrenčić and M. Čubrilo, "Ontologies in the Higher Education Domain," Proc. 18th Int. Conf. Inf. Intell. Syst., no. February, 2015.

24.N. Zaini, M. F. Abdul Latip, and H. Omar, "Semantic-based online outcome-based education measurement system," 2011 3rd Int. Congr. Eng. Educ. Rethink. Eng. Educ. W. Forward, ICEED 2011, pp. 218-222, 2011.

25.A. Y. Alsobhi, N. Khan, and H. Rahanu, "Personalised learning materials based on dyslexia types: Ontological approach," Procedia Comput. Sci., vol. 60, no. 1, pp. 113-121, 2015.

26.E. Nyitrai and B. Varga, "Ontology-based higher educational information systems," Pollack Period., vol. 7, no. 3, pp. 139-148, 2012.

\section{AUTHORS PROFILE}

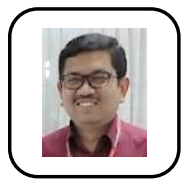

Bagus Mulyawan He got his bachelor's degree from the Computer Engineering Department, Gunadarma University, Indonesia, in 1992. He obtained his master's degree in Information System from Budi Luhur University, Jakarta, Indonesia, in 2008. Now, he is a student at BINUS Graduate Program, Doctor of Computer Science, Bina Nusantara University and lecturer at the Faculty of Information Technology, Universitas Tarumanagara. Research area Information system, and data mining.

Dr. Meyliana is a lecturer. He has a Doctor of Information Sytem from Indonesia University. His research area includes customer relationship management, blockchain 
Prof. Dr. Achmad Nizar Hidayanto is a lecturer. He has a Doctor of Information System from Indonesia University. His research area includes Information Systems, IT Adoption, Digital Economy, and Financial technology

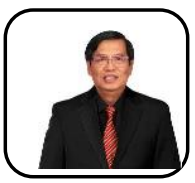

Prof. Dr.Harjanto Prabowo is a lecturer. He has a Doctor of business management from Padjadjaran University. His research area includes strategic management, knowledge management 